DOI: http://dx.doi.org/10.33846/hn30406

http://heanoti.com/index.php/hn

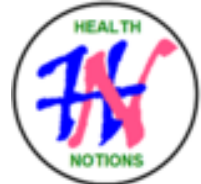

RESEARCH ARTICLE

URL of this article: http://heanoti.com/index.php/hn/article/view/hn30406

\title{
The Effectiveness of Mentoring Cadres in Baby Care in Blang Bintang Sub-District,
} Aceh Besar, Indonesia

\author{
Anita $^{1(\mathrm{CA})}$ \\ ${ }^{1(\mathrm{CA})}$ Department of Midwifery, Health Polytechnic of Aceh, Indonesia; anita@ poltekkesaceh.ac.id \\ (Corresponding Author)
}

\begin{abstract}
Introduction: A number of babies born in Aceh were 100,365 people in 2018. About 1,189 babies were declared dead. One of the ways to reduce mortality is that a cadres mentoring program has been carried out in rural villages. Purpose: To understand the effectiveness of cadre mentoring on baby care in Blang Bintang SubDistrict, Aceh Besar District. Methods: The method of this study was a cross-sectional design. The population was 205 of the infants in Blang Bintang sub-district in 2018. Samples were infants $<12$ months according to inclusion criteria, as many as 50 respondents. Data analysis using descriptive analysis, Chi-Square test and logistic regression test, with a 95\% confidence interval. Results: Mentoring cadres was effective in baby care. There was a consistently significant relationship between the effectiveness of cadre assistance to infant care with a p-value of 0.048 . The results of statistical tests showed that the existence of cadre mentoring provides effective results in improving infant care $(\mathrm{CI}=1.17-12.19)$. Babies who got cadre assistance had a 3.77 times chance of getting better care compared to babies who don't get assistance. Conclusion: Cadre assistance is very effective for baby care and health promotion for mothers. Cadre assistance could also increase knowledge, provide health information, reducing infant and toddler morbidity and mortality.
\end{abstract}

Keywords: Infants care, Cadres mentoring, Indonesia

\section{INTRODUCTION}

\section{Background}

The Ministry of Health's 2015-2019 Strategic Plan (RENSTRA) on the Healthy Indonesia Program is implemented through three pillars covering the healthy paradigm, strengthening health services and national health insurance. ${ }^{(1)}$ One of the goals of the health service delivery pillar is to reduce infant mortality. Because a baby is a group prone to death that needs special care to avoid death and suffering from malnutrition ${ }^{(2)}$ One of the strategic programs reduces infant mortality and Prevention Planning Program Delivery Complications. For that effort enhancing the health of infants will require the cooperation of families and communities in providing health care for mothers and newborns. The Indonesian Demographic and Health Survey (IDHS) in 2017 shows $60 \%$ of dead babies occur at the age of 1 month. With the neonatal mortality rate was 19 deaths per 1,000 births. As many as $80 \%$ of babies die when they are 1-11 months old, with a post-neonatal mortality rate of 13 deaths per 1,000 births ${ }^{(2)}$ Currently, the Infant Mortality Rate (IMR) in Aceh in 2018 is 1,189 people and the number of live births is 100,365 people. Efforts to reduce infant mortality are carried out with cadre mentoring programs. Cadre assistance through weekly home visits or to the health community center can reduce the incidence of infant mortality. Cadre assistants in providing baby care in the community have been shown to significantly reduce the number of infant deaths ${ }^{(3)}$. Cadre assistance participation plays a role in the level of success of Posyandu so that it can achieve the optimal nutritional status of children. ${ }^{(4)}$ Aceh Besar District is one of the districts that has implemented cadre assistance systems for baby care. The results of observations and preliminary studies at the Blang star community health center revealed that there were 205 babies in 2018, with 
133 cadres in 26 villages. The purpose of this study was to analyze the effectiveness of cadre assistance to infant care in Blang Bintang District, Aceh Besar.

\section{METHODS}

The type of research used was observational with a quantitative approach and cross-sectional design. This study was conducted in October up to December 2018 Blang Bintang District Health Clinics. The location of the study was conducted purposefully, namely at Blang Bintang Health Center, Aceh Besar Regency, Aceh Province. The population in this study were all 205 infants in Blang Bintan Sub-district. The sample in this study were infants aged 0 to $<12$ months, which amounted to 50 people according to the inclusion criteria. The sampling technique was done in two stages. The first stage was purposive sampling technique determines the village by taking 5 villages from 26 villages in Blang Bintang District. The second stage was total sampling, all babies in 5 selected villages were taken as respondents. Data analyses used the Chi-square dan logistic regression test.

\section{RESULTS}

This research was conducted from October to December 2018 in Blang Bintang District, Aceh Besar. The subjects of this study were infants $<12$ months old, and data were obtained from mothers who had babies.

\section{Descriptive Analysis}

Table 1. Frequency distribution of research variables effectiveness of cadre assistance to baby care in Blang Bintang District, Aceh Besar District

\begin{tabular}{ccc}
\hline Variables & Frequency & Percentage \\
\hline Baby Care & & \\
Well & 26 & 52 \\
Less & 24 & 48 \\
\hline Total & 50 & $100 \%$ \\
\hline Assistance to Cadres & & \\
\hline There is & 25 & 50 \\
There is no & 25 & 50 \\
\hline Total & 50 & $100 \%$ \\
\hline
\end{tabular}

The table 1 shows good baby care reaching 52\%. Whereas $25(50 \%)$ of cadres who do it with assistance.

\section{Bivariate analysis}

Bivariable analysis was conducted to determine the relationship between the effectiveness of cadre assistance and infant care. This analysis uses the Chi-square test $(\chi 2)$ statistical test, with calculations of Odds Ratio(OR) and 95\% confidence interval (CI), at a significance level of $\mathrm{p}<0.05$.

Table 2. Analysis of the effectiveness of cadre assistance to infant care in Blang Bintang Sub-District, Aceh Besar District 2018

\begin{tabular}{|c|c|c|c|c|c|c|c|}
\hline \multirow[t]{2}{*}{ Variable } & \multicolumn{4}{|c|}{ Baby Care } & \multirow[t]{2}{*}{ p-value } & \multirow[t]{2}{*}{ OR } & \multirow[t]{2}{*}{$95 \% \mathrm{CI}$} \\
\hline & & & & ess & & & \\
\hline \multicolumn{8}{|c|}{ Mentoring assistance } \\
\hline there is & 17 & 65.4 & 8 & 33.3 & 0.048 & 3.77 & $1.17-12.19$ \\
\hline there is no & 9 & 34.6 & 16 & 66.7 & & & \\
\hline
\end{tabular}

The results of the analysis showed that cadre mentoring had a significant influence on infant care . Babies who get cadre assistance have a chance of 3.77 times to get better care compared to babies who do not get assistance. 


\section{DISCUSSION}

Cadre mentoring is an effective way to improve the ability of the community, especially mothers in infant care. The results of the bi-variable analysis between the independent variables of cadre assistance effectiveness and the dependent variable of infant care showed significant results. Babies who get cadre assistance have a chance of getting better care compared to babies who do not get assistance. The results of statistical tests show that the existence of cadre mentoring provides effective results in improving infant care. Practically there was an increase in infant care after being given cadre assistance. The existence of a companion Cadre functions as a health care provider through health education and training. The results of the study ${ }^{(5)}$ assisted adherents to provide benefits specifically in improving the health of infants through care for, immunization, promoting breastfeeding, and in an effort to reduce the morbidity and mortality of infants and toddlers. The participation of cadre mentors can increase maternal knowledge and improve the health of the baby. Study of ${ }^{(6)}$ cadre knowledge can encourage success in increasing maternal knowledge. This situation shows that increasing cadre knowledge can improve the quality of cadres in terms of providing nutrition and health education at the posyandu ${ }^{(7)}$. In fact, cadre assistance is expected to be a potential driving force, especially in the delivery of knowledge and nutritional messages ${ }^{(8)}$. Cadre assistance provides effective and relatively inexpensive interventions in health education and can reduce the incidence of infectious diseases in rural areas

(9). Meanwhile, the participation of mothers and cadres plays an important role in the success rate of care so that it can achieve the optimal nutritional status of children under five ${ }^{(4)}$ Green \& Kreuter's research also said that health education through cadre mentoring can influence maternal health behavior about newborn care. The active role of cadre assistance in providing information and health education is very much needed ${ }^{(10)}$. Interventions in the form of nutrition counseling and participation are expected to increase knowledge, attitudes, and nutrition practices ${ }^{(11)}$. Cadre assistance is effective in caring for the baby and socializing health to the mother.

\section{CONCLUSION}

Mentoring Cadres is effective in baby care. Babies who get cadre assistance have higher chance of getting better care compared to babies who don't get assistance. The results of statistical tests show that the existence of cadre mentoring provides effective results in improving infant care $(\mathrm{CI}=1.17-12.19)$. Cadre assistance is very effective for baby care and health promotion for mothers. Cadre assistance can also increase knowledge, provide health information, reduce infant and toddler morbidity and mortality.

\section{REFERENCES}

1. MoH-RI. Ministry of Heath Letter Number HK.02.02/MENKES/52/2015 on Ministry of Health Strategic Planning Year 2015 - 2019. Jakarta: Ministry of Health of Republic of Indonesia; 2015.

2. MoH-RI. Minister Regulation No. 43 of 2016 on Minimum Service Standards of Health Sector. Jakarta: Ministry of Health of Republic of Indonesia; 2016.

3. Gogia S, Sachdev HS. Home visits by community health workers to prevent neonatal deaths in developing countries: A systematic review. Bull World Health Organ. 2010;658-666B.

4. Sharma N, Malla H, Thapa N, Aryal K, Vitrakoti R, Bhandari RM. Community participation and mobilization in community-based maternal,newborn and child health programmes in Nepal. J Nepal Health Res Counc. 2011;19:101-106.

5. Lewin S, Babigumira SMB. Lay health workers in primary and community health care for maternal and child health and the management of infectious diseases (Review), USA: John Wiley \& Sons, Ltd.; 2010.

6. Mbuya MNN, Menon P, Habicht JP, Pelto GH, and Ruel MT. Maternal knowledge after nutrition behaviorchange communication is conditional onboth health workersknowledge andknowledge-sharing efficacy in Rural Haiti. J. Nutr. 2013;113:178442.

7. Naidu A. Factors affecting patient satisfaction and healthcare quality. Int. J. Health Care Qual. Assur. 2009; 22(4):366-381.

8. Agrawal PK, Srivastava VK.. Effect of knowledge of community health workers on essential newborn health care: a study from rural India. Health Policy Plan. 2012;27:115-126.

9. Mosquera PA, Hernandez J, Vega R, Martinez J, Labonte R, Sanders D, and Sebastian MS. Primary health care contribution to improve health outcomes in Bogota-Colombia: a longitudinal ecological analysis. BMC Family Practice. 2012;13:84.

10. Green L, Kreuter M. Health Promotion Planning an Educational and Environment Approach. Mountain View: Mayfield Publishing Company; 2000. 
11. Thakur SK, Roy SK, Paul K, Khanam M, Khatun W,Sarker D. Effect of nutrition education on exclusive breastfeeding for nutritional outcome of low birth weight babies. European Journal of Clinical Nutrition. 2011;5:1-6. 